International Journal of Instruction e-ISSN: 1308-1470 • www.e-iji.net
July $2018 \bullet$ Vol.11, No.3
p-ISSN: $1694-609 X$
pp. 193-206

Received: 21/11/2017

Revision: 03/03/2018

Accepted: 08/03/2018

\title{
School Self Evaluation Model Suggestion
}

\section{Şeyma Şahin}

Phd Student, Düzce University, Turkey, seyymasahin@gmail.com

\section{Abdurrahman Kılıc}

Prof., Düzce University, Turkey, abdurrahmankilic@duzce.edu.tr

This research aims to create a School Self Evaluation Model which will enable schools to evaluate their own educational practices. Qualitative research method is adopted in the research. Research data were collected through literature review and document analysis. Opinions about the usefulness and consistency of the developed model in respect to literature review and document analysis are taken from four experts on educational sciences. In this study, descriptive document analysis method is used in the analysis of data. In the light of the information obtained from the literature, the two main categories and five sub-categories that will form the basis of the document analysis have been predetermined. Then, 16 documents considered suitable for use creating a model of the end-result of the literature review have been read in the context of these categories and the obtained data is divided into these two basic categories and five sub-categories and it is summarized. A holistic image was tried to obtain by supporting the obtained data with the existing literature and School Self Evaluation Model is created.

Keywords: evaluation, self evaluation, school evaluation, evaluation model, model suggestion

\section{INTRODUCTION}

Evaluation; is the process of collecting the data systematically and analysing to determine the values or the benefits of the objects and to create a standard of judgement that is based upon valid evidences (Stufflebeam \& Shinkfield, 1988; Rogers \& Badham, 1992). Wholey, Hatry \& Newcomer (2004) consider evaluation of a valuable learning strategy that is used to reach the information about the logic of the programs and the practical results.

School evaluation is a type of assessment designed to assess information about the quality of practices at school, assess what does not work and what does not serve the purpose, and specifically determine what changes need to be made to achieve school goals (Department of Education and Skills, 2016; Education Review Office, 2016). School evaluation, an effort to understand the quality of processes and products, is a key 
factor for learning schools (MacBeath \& Sugimine, 2003). School evaluation contributes to school development in several ways. The first of these is to serve for the formation of a performance-focused school culture. It also contributes to the increase in educational performance and standardization in education (Hanberger, Carlbaum, Hult, Lindgren \& Lundström, 2016).

School self evaluation, also called internal school evaluation can be defined as school program or staff performing school basic services evaluating the performance of their schools (Nevo, 2002). Purpose of self evaluation, is to raise the standards that apply to more effective learning and teaching. Effective schools are constantly reviewing their own practice and seeking ways to make the school better (Department of Education and Skills, 2016). With self evaluation, schools are directed to determine their educational goals, be responsible for their own educational processes, and evaluate their own actions. With self evaluation, it is aimed not only to support improvement but also to meet the accountability requirement of the school (Nevo, 2002). Self evaluation is seen as an assistant of professional development. Teachers and other staff will become selfaware, higher self-reflective, and more self-critical individuals by self evaluation, following their own performance and professional development (Ainsworth, 2010; MacBeath, 2006).

School self evaluation may be conducted under the leadership of a teacher or a group of teachers, a school principal or other school administrator, or a special officer designated by the school as an evaluator (Nevo, 2002). It is recommended to establish an evaluation committee for an effective evaluation. In this commission; it is preferred that all stakeholders, such as students, teachers, parents, school management, are involved (MacBeath, Schratz, Meuret \& Jakobsen, 2000). Schools can get "critical friends" to work with them to do their own self evaluation of their own development. A critical friend is a person who asks for thoughtful questions, makes a review of the data from another point of view and makes constructive criticism (MacBeath, et al., 2000). In this way, shared vision, strong support, nurturing and honest self evaluation will bring about the changes schools need (Baskerville \& Goldblatt, 2009).

Being different aspects of evaluation objectives and focuses, evaluation context, target audience, evaluation opportunities (time and resources), and different viewpoints of evaluators' concepts of program and evaluation cause differentiation and diversification of approaches and models to be used in evaluation process. This situation results in also requiring evaluators to consider new evaluation designs and to enter into new model searches in addition to being used in evaluation studies by selecting from the existing models. Erden (1998) suggests that researchers can develop a new model by using different models, as it is not necessary to use a single model in the program evaluation studies, it can be taken in every model as appropriate for the purpose and type of the research. The evaluators themselves can form a relational model showing how the evaluation program will work. The goal in model building is to make a complex process understandable and practicable. The development of such a model helps to establish a common understanding and expectation between program evaluators and program stakeholders (Wholey, Hatry \& Newcomer, 2004). 
When the literature is examined, it is seen that evaluation models are generally inspired from different models and made various arrangements on them. Saylor, Alexander \& Lewis (1981) synthesized different models and developed a comprehensive and multidimensional evaluation model. Metfessel and Michael formed their own evaluation models towards the end of the 1960s, based on the principles contained in Tyler's model (Ornstein \& Hunkins, 2009). Demirel (1992) has developed a model fitting to the TabaTyler model in line with the views of program development experts. Ertürk's Curriculum Evaluation and Development Model is developed by taking advantage of Tyler and Bloom (Sönmez \& Alacapınar, 2015).

When international evaluation studies are examined, it has been observed that evaluators often use their own models produced by themselves and generally have not included the building process of the models in the studies. In some of the investigated studies, literature review and document analysis methods are used in the model development process. For example, the Florida School Leader Evaluation Model is developed based on contemporary research on educational leadership behaviours that are thought to have a positive impact on student learning and using the Florida State Education Leadership Standards (Florida Department of Education, 2012). The Marzano Teacher Evaluation Model can be thought of as a combination of research on items that are traditionally thought to correlate with the academic achievement of students. It is developed based on Marzano's past research and a detailed meta-analysis study of John Hattie's student achievement (Learning Sciences Marzano Center, 2013).

In this context, this research aims to create a School Self Evaluation Model that will enable schools to evaluate their own educational practices. For this purpose, the answers to the following questions are searched:

1. What are the aims and basic characteristics of the School Self Evaluation Model?

2. What are the processes of the School Self Evaluation Model and the operations performed in the processes?

\section{METHOD}

\section{Research Model}

Qualitative research method is adopted in the research. Qualitative research is a research method that focuses on the meanings, definitions, characteristics, symbols and explanations of the concepts studied (Berg, 2001). By contributing to the realistic and holistic gathering of the data in the natural environment and by showing how people understand their lives and worlds (Merriam, 2009), it provides the researcher a detailed analysis and explanation of the essence and quality of human experience (Marvasti, 2004).

\section{Data Collection Methods}

Research data were collected through literature review and document analysis. The purpose of literature review; is to place new research problem on fund of knowledge by scanning all the written information to see what is already known about a topic (Sapsford \& Jupp, 2006). Document analysis; is the systematic review of available 
resources in order to collect verifiable data and information (Watkins, Meiers \& Visser, 2012). Documents; are ready-made data sources that will enable researchers to obtain information they cannot reach through interviews and observations (Mason, 2002, Merriam, 2009). Opinions about the usefulness and consistency of the developed model in respect to literature review and document analysis are taken from four experts on educational sciences.

\section{Data Collection}

The following steps were followed in the data collection process of the study:

- Literature is scanned in a detailed way on the concepts of "evaluation", "self evaluation", "school evaluation" and "school self evaluation".

- Evaluation models (target-oriented, system-based, collaborative, democratic, participatory, competitor-oriented, expert-oriented evaluation models) in the literature have been examined in detail.

- The school evaluation and school self evaluation models in the literature and applied researches about school evaluation and school self evaluation in Turkey and abroad have been examined in depth.

- It has been found that the evaluation philosophies of the "David Fetterman's Empowerment Evaluation Model" (Fetterman \& Wandersman, 2005) and "Stake's Countenance Model" (Stake, 1967) are found appropriate to create a school self evaluation model and these two documents have been analyzed. Based on these two models and in the light of the literature review mentioned in the first three items, basic characteristics and aims of the School Self Evaluation Model have been determined.

- The literature survey was conducted on the topics mentioned in the first three items while determining the processes of the School Self Evaluation Model, the operations carried out in the processes, the dimensions of the evaluation and the areas of evaluation and at the result of this literature search, it is decided to analyse the documents of "Standards and Accreditation System in Teacher Training in Turkey" (Yüksek öğretim Kurulu, 1999), "School Based Professional Development Model" (MEB, 2010), "School Based Development Model" (Ankara İl Milli Eğitim Müdürlüğü, 2016), and "Vocational and Technical Education Self Assessment Model" (Mesleki ve Teknik Eğitim Genel Müdürlüğü, 2014). Based on these documents and the information obtained from and the literature review mentioned in the first three items, the processes of the model, the operations carried out in the processes, the dimensions of the evaluation and the areas of evaluation are determined.

- The literature on teacher competencies and effective teacher characteristics has been examined in detail in order to form components of the "teacher" evaluation area in the "process" dimension of the School Self Evaluation Model and two main documents considered to provide a detailed and consistent perspective on teacher competences have been examined. These documents are; "Marzano Teacher Evaluation Model" (Learning Sciences Marzano Center, 2013) and "Ministry of National Education General Teacher Proficiency Competencies" (Öğretmen Yetiştirme Genel Müdürlüğü, 2002). The findings obtained from the analysis of these two documents are supported by related literature and components of the teacher evaluation field are established. 
- The literature on leadership, effective school, school leadership, and educational leadership has been examined in detail in order to establish the components of the "school management" evaluation area in the "process" dimension of the School Self Evaluation Model and four documents are decided to be analysed. These documents are; "Marzano School Leadership Evaluation Model" (Learning Sciences Marzano Center, 2012), "Educational Leadership Policy Standards" (National Policy Board for Educational Administration, 2008), "Self Evaluation of School Leadership" (Department of Education and Skills, 2015), "Florida Department of Education School Leader Evaluation System" (Florida Department of Education, 2012). The results obtained from the analysis of these four documents are supported by related literature and components of the teacher evaluation field are established.

- In order to form the components of the "student" evaluation area of the "process" and "product" dimensions of the School Self Evaluation Model, the existing literature on student-centred education, 21st century student competencies and the factors affecting student success are scanned in detail. Later, the knowledge, skills and values in the secondary and high school curriculums of the Ministry of National Education are examined. Two documents are selected for analysis as a result of the literature review. These documents are; "P21 Framework Definitions" (Partnership for 21st Century Learning, 2015) and "Assessing of 21st Century Skills: Summary of a Workshop" (National Research Council, 2011). The findings of the analysis of these two documents are supported by the related literature and the components of the student evaluation field are established.

- A comprehensive literature survey is conducted on issues such as the duties and responsibilities of the family, the school-family relationship, and the effects of the family on the students, in order to form the components of the "family" evaluation area of the "process" dimension of the School Self Evaluation Model. The document "National Standards for Family-School Partnerships" (Parent Teacher Association, 2009), which is thought to provide a detailed and consistent perspective on this issue, has been analyzed. This document is taken as a basis and the evaluation area components are created with the support of the related literature.

- A comprehensive literature survey of the functions of the guidance service, the characteristics of an effective guidance service, has been made in order to establish the components of the "guidance service" evaluation area of the "process" dimension of the School Self Evaluation Model. A document called the "ASCA National Standards for Students" (American School Counselor Association, 2004), which is thought to provide detailed information on this issue, has been analyzed. The results of the analysis of this document are supplemented by the relevant literature and components of the guidance service evaluation area are established.

\section{Data Analysis}

Every research based on a document review has different characteristics in terms of both the sources and the content of the resources, and requires some new approaches in the data analysis phase. For this reason, it is compulsory that the researcher develops a data analysis plan that will be the basis for his research (Şimşek, 2009). In this study, 
descriptive document analysis method is used in the analysis of data. Descriptive analysis method is a method that aims to examine the facts and meanings of the research systematically (Bryman, 1988; Lincoln \& Guba, 1985).

In the analysis process, concepts such as 1. "evaluation", "self-evaluation", "school evaluation", "school self-evaluation", 2. evaluation models, 3. applied research on school evaluation and school self-evaluation, and 4. school evaluation and school selfevaluation models are examined in detail. In the light of the information obtained from the literature, the two main categories and five sub-categories that will form the basis of the document analysis have been predetermined. These main categories are; 1. Objectives and key features of the school self-evaluation model, and 2. Processes in school self-evaluation model and operations in the processes. The five subcategories under category 2 are; 1. Preparation, 2. Monitoring, 3. Evaluation, 4. Planning and 5. Application categories. Then, 16 documents considered suitable for use creating a model of the end-result of the literature review have been read in the context of these categories and the obtained data is divided into these two basic categories and five subcategories and it is summarized.

\section{FINDINGS}

\section{Objectives and Basic Characteristics of the School Self Evaluation Model \\ Objectives of the School Self Evaluation Model}

The objectives of the School Self Evaluation Model are in two categorizes; direct and indirect objectives. Direct and indirect objectives are shown in Table 1:

Table 1

Objectives of the School Self-Evaluation Model

\begin{tabular}{|c|c|}
\hline $\begin{array}{l}\text { Direct } \\
\text { Objectives }\end{array}$ & $\begin{array}{l}\text { Identification of what is unuseful in school practices and what does not work } \\
\text { Identification of what changes need to be made to achieve school goals } \\
\text { Identification of the priorities for improvement }\end{array}$ \\
\hline & To help establish an effective assessment culture in school \\
\hline & To contribute to the formation of a performance-focused school culture \\
\hline Indirect & To contribute to standardization \\
\hline Objectives & $\begin{array}{l}\text { Educational and psychological strengthening of school staff by offering } \\
\text { opportunities for collaboration, evaluation, participation in decision-making } \\
\text { processes and managing resources }\end{array}$ \\
\hline
\end{tabular}

Basic Characteristics of the School Self Evaluation Model

The main features of the School Self Evaluation Model are described below:

- Self evaluation. School Self Evaluation Model is based on the identification of a school's effectiveness from the perspective of the school through self evaluation method. An evaluation commission is formed for this purpose. In this commission; it is preferred that all stakeholders, such as students, teachers, parents, school management, are involved.

- Cooperation. The School Self Evaluation Model requires the evaluator or evaluators to work collaboratively with the operator. The task of the evaluator is to 
guide the process of program evaluation and to serve as a coach facilitating this process. The evaluator assists in the collection of accurate information throughout the process. The evaluator, who can also function as a "critical friend", is a person who asks for thoughtful questions, a person who examines the data from a different point of view and makes constructive criticism.

- Participation of all Stakeholders. The School Self Evaluation Model adopts the understanding that all stakeholders (teachers, managers, students and parents) participate at every stage of the evaluation process, including data collection, data analysis and reporting. The task of the evaluator is to take part in the evaluation, not to fully control the evaluation process.

- Focusing on Daily Practices and Process. The School Self Evaluation Model adopts an approach that focuses on the practices and processes involved in day-to-day operation of the school and the classroom.

- Evaluating the School as a Whole. The School Self Evaluation Model adopts the idea that the functioning of the school should be evaluated as a whole together with all aspects and items. The effectiveness of the school; should be considered as a whole, not just the quality of some elements such as students, teachers, or school management. In order to be able to assess the effectiveness of the school at the highest level, it emphasizes to focus on the school as a whole, in other words 'to the big picture'.

- Comparison of Current Situation and Needed Situation. School Self Evaluation Model is based on the basis of the analysis of the current situation and its comparison with the situation that is needed.

- Cyclical Process. School Self Evaluation Model is a cyclical process and this cyclical process consists of five phases. These steps are preparation, monitoring, evaluation, planning and implementation phases.

- Action Research. School Self Evaluation Model is performed in the form of action research. Action research is a practical, cyclical, and problem-solving oriented approach. In this approach, it is aimed that operators acquire new knowledge, skills and experiences, and that operators gain a critical perspective to their own practice. The data collected during the monitoring process are analyzed in the evaluation process and some results are achieved. Then it is tried to find rational solutions to the problems that exist in the direction of these results and some suggestions are developed. A new action plan is prepared and put into practice in line with these solutions and suggestions.

- Input, Process and Product Dimension. Monitoring process in the School Self Evaluation Model; input, process and product. Input is any situation that affects processes and products and exists before the learning teaching process. The process can also be named as learning teaching process. Products are the short-term and long-term impacts of the process dimension on students' learning, skills and value acquisitions.

- Standards and Decision Criteria. School Self Evaluation Model emphasizes the importance of standards and decision criteria. There is no evaluation according to intuition and prejudice. These standards are not universal, and may vary by school and subject. Evaluation standards that are quite appropriate for a school may not be appropriate for another school. For this reason, the evaluation standards should be determined in cooperation with the evaluator and the school evaluation team. 
- Multiple Data Collection Methods. The School Self Assessment Model adopts the use of multiple data collection methods (interview, observation, document review, scales, tests, questionnaires). Both qualitative and quantitative methods are used in combination to gather rich and persuasive information.

\section{School Self Evaluation Model Processes and Operations Performed in Processes}

Evaluation according to the School Self Evaluation Model is a cyclical process and this cyclical process consists of five phases. These steps are preparation, monitoring, evaluation, planning and implementation phases. Firstly, necessary preparations are made and the current situation is analyzed and various judgments are reached. Then a new plan is made for the future and this planning is implemented. The processes of the School Self Evaluation Model and the operations that are needed to be done in each process are described below:

\section{Preparation Process}

Preparation process includes the period from the creation of the evaluation team to the start of data collection. The following operations are expected to be carried out during the preparation process: 1 . Creation of evaluation team, 2. Determination of evaluation objectives linked to evaluation priorities, 3. Distributing the duties, 4. Preparation of business calendar, 5. Training the evaluation team about necessary topics such as evaluation model, data collection methods and data analysis methods, 6. Identification of information sources and data collection methods, 7. Establishing performance standards, 8. Creation of data collection tools.

It is suggested that School Self Evaluation team should be consisted of the evaluator (1), teachers (4-6), manager (1), assistant principals (2), head of school family association (1) and the student representative (1). For evaluation purposes, it may be appropriate to establish a team of 10-12 people, although this may vary according to the scope of the evaluation and the available facilities. It is preferable that the teachers who will take place on the evaluation team are selected from the Branch Teachers' Committee leaders, but the principle of volunteerism should be taken into consideration.

\section{Monitoring Process}

The monitoring process is the stage in which evaluation data are collected. In this process, rich and persuasive information is collected by using qualitative and quantitative data collection methods from various data sources (teachers, students, administrators, parents, etc.). For this purpose, data collection methods such as interviewing, observation, document examination, scales, tests, questionnaires etc. can be used. How long the monitoring process will last can change according to the purposes of evaluation, the scope of the assessment, available facilities. The monitoring process occurs in three dimensions as "Input", "Process" and "Product". All assessment dimensions of the model interact eachother.

Inputs are conditions that exist prior to the learning teaching process. As input in the School Self Evaluation Model; "Curriculum", "Teacher", "School Management", "Student", "Family", "Guidance Service", "Physical Resources" are determined. The process dimension can also be called the learning teaching process. In the process 
dimension, the effects on different aspects of education are tried to be examined. Goal is to understand the positive and negative situations in the school and classroom environment. In the process dimension of the School Self Assessment Model; "Teacher", "School Management", "Student", "Family", "Guidance Service", "Physical Resources" will be evaluated. Products are short-term and long-term effects of the process size on the learning, skills and value acquisitions of students.

\section{"Input" Dimension}

The "input" dimension consists of seven evaluation areas. These evaluation areas are; "Curriculum", "Teacher", "School Management", "Student", "Family", "Guidance Service" and "Physical Resources".

Curriculum applied on a per-course basis in the school will be assessed in the objectives, content, learning situations, and testing situations. "Teacher", "School Management" and "Student" evaluation areas will be examined from the points of number, election process, demographic characteristics, readiness, educational status, etc. The "Guidance Service" will be reviewed in terms of resources (teacher, physical facilities, materials), authority and responsibilities. "Family" will be examined from the points of demographic characteristics, socio-economic status, education and so on. In the evaluation field of "Physical Resources", library, dining hall, dormitory, classrooms, laboratories, prayer room, canteen and so on. physical possibilities will be examined. Components of the "Curriculum" and "Physical Resources" in the input dimension will be evaluated indirectly by the components involved in the process dimension, based on their use.

"Process" Dimension

The "process" dimension consists of five evaluation areas. These evaluation areas are; "Teacher", "School Management", "Student", "Family" and "Guidance Service". Each evaluation area and components are listed below:

"Teacher" Evaluation Area

- Planning/Preparation to the lesson

- Learning Teaching Process

- Evaluation/Monitoring/Feedback

- Relationship with Student

- Professional Development/Responsibility/Cooperation

- School, Family and Community Relations

"School Management" Evaluation Area

- Organization/Resource Management

- Teaching Leadership/Student Achievement

- School Culture

- Application of Curriculum

- Supporting School Development

"Student" Evaluation Area

- Social Relations/Communication

International Journal of Instruction, July $2018 \bullet$ Vol.11, No.3 
- Attitude Toward School/Learning

- Participation in Learning Process

- Environmental Relations/Use of Resources

"Family" Evaluation Area

- Positive Parenting

- Supporting Student Achievement

- Effective Communication with School

- Participation in School Decisions

"Guidance Service" Evaluation Area

- Academic Development

- Career Development

- Personal/Social Development

"Product" Dimension

The "Product" dimension consists of the "Student" evaluation field, which is the only evaluation field. The student evaluation area consists of three components. These components are; Information, Skill and Values. Information consists of three components, "Cognitive", "Affective" and "Psychomotor". The skill consists of three components: "cognitive" (problem solving, critical thinking, systematic thinking etc.), "interpersonal" (communication, collaborative work, cultural sensitivity, leadership, responsibility, conflict resolution, empathy, etc.) and "internal" (self-management, selfregulation, self-evaluation, time management, personal development, adaptation, creativity and innovation, courage, ethics, etc.).

\section{Evaluation Process}

During the evaluation process, the collected data are analyzed and some results are obtained. There are some judges in the direction of these results afterwards. The following activities are expected to be carried out during the evaluation process: 1 . Analysis of the data, 2. Comparison of existing data and performance standards, 3. Access to standard of judgments, 4. Writing the evaluation report.

\section{Planning Process}

During the planning process; a new planning is made in line with the results obtained in the evaluation process and the value judgments reached. For this purpose, opportunities for change and options are considered and the elements of the new action plan are determined. The following activities are expected to be carried out in the planning process: 1. Determination of priorities, 2. Identification of possible solutions, 3. Preparation of new action plan.

\section{Implementation Process}

The final stage of the School Self Evaluation Model is the implementation process. In this process, the action plan prepared in the planning process is put into practice.

\section{CONCLUSION}

Purpose of self evaluation is to raise the valid standards for more effective learning and teaching. Effective schools are constantly reviewing their own practice and seeking ways 
to make the school better. School management and teachers focus on the quality of the learning-teaching process in schools and student achievement. They also think about how well the school is managed and how it will be developed (Department of Education and Skills, 2016). With self evaluation, schools are directed to determine their own educational goals, be responsible for their own educational processes, and evaluate their own actions. With self evaluation, it is aimed not only to support improvement but also to meet the accountability requirement of the school (Nevo, 2002). There is a direct link between professional development and school self evaluation. Self evaluation is seen as a facilitator of professional development. Teachers and other staff will become selfaware, higher self-reflective, and more self-critical individuals by self-evaluation, following their own performance and professional development (Ainsworth, 2010; MacBeath, 2006). In this context, this research aims to create a School Self Evaluation Model which will enable schools to evaluate their own educational practices by using national and international literature. The School Self Evaluation Model created for this purpose is shown in Figure 1:

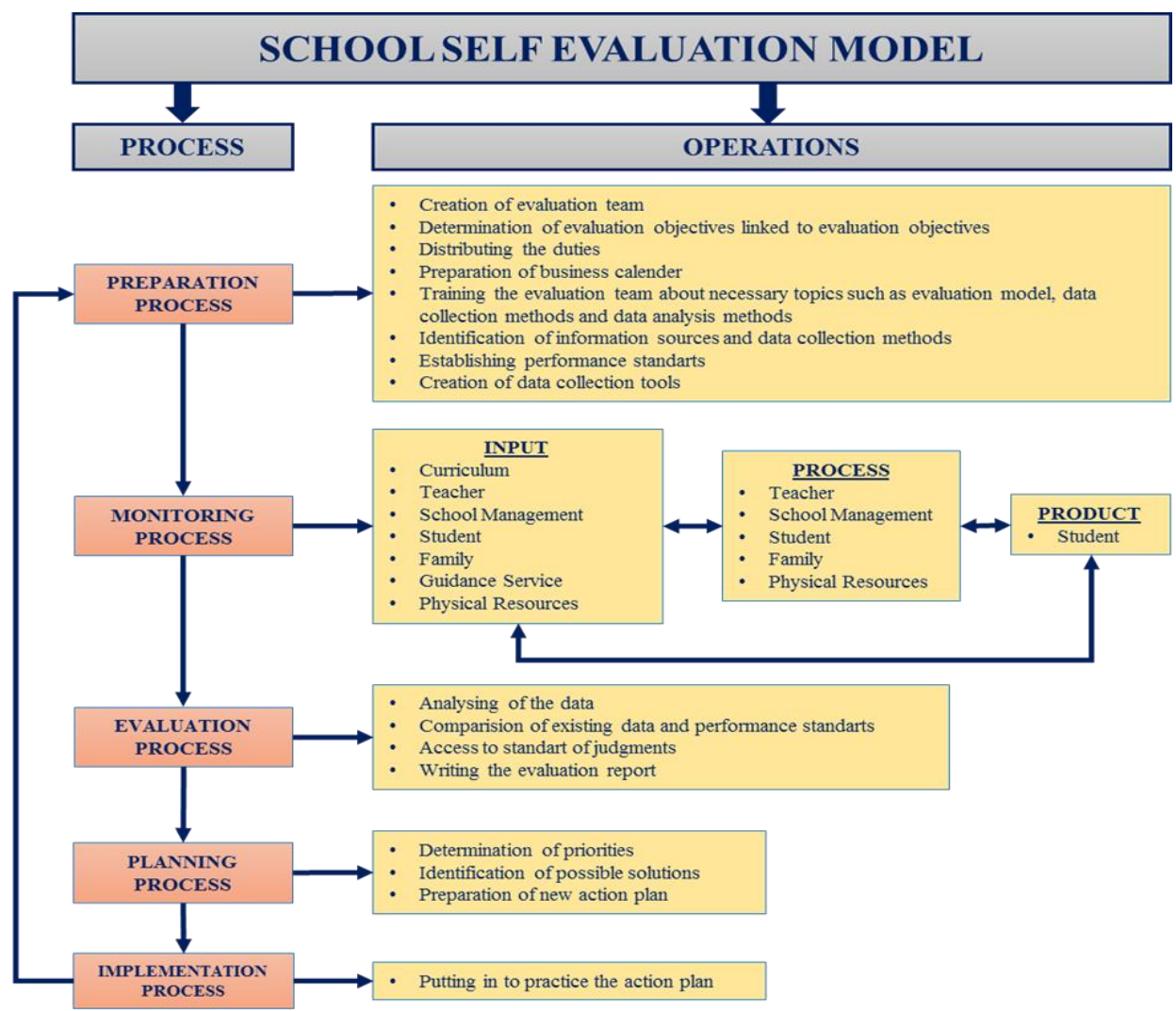

Figure 1

School Self Evaluation Model

International Journal of Instruction, July $2018 \bullet$ Vol.11, No.3 


\section{SUGGESTIONS}

- Schools should be encouraged by their authority to conduct their own selfevaluations.

- This model can be tested at self-evaluation studies. After these applications, improvements can be made on the model.

- Evaluators should develop their own models according to the situations like evaluation objectives, evaluation context, target audiences, and evaluation opportunities.

\section{REFERENCES}

Ainsworth, P. (2010). Developing a self-evaluating school: A practical guide. NY: Continuum International Publishing Group.

American School Counselor Association (2004). ASCA national standards for students. Alexandria, VA, 1-12.

Baskerville, D., \& Goldblatt, H. (2009). Learning to be a critical friend: From professional indifference through challenge to unguarded conversations. Cambridge Journal of Education, 39(2), 205-221.

Berg, B. L. (2001). Qualitative research methods for the social sciences. USA: Allyn and Bacon.

Bryman, A. (1988). Quantity and quality in social research. London \& New York: Routledge.

Demirel, Ö. (1992). Türkiye'de program geliştirme uygulamaları. Hacettepe Üniversitesi Eğitim Fakültesi Dergisi, 7, 27-43.

Department of Education and Skills (2015). Self-evaluation of school leadership: Domains, standards and statements of practice. Dublin: The Inspectorate.

Department of Education and Skills (2016). School self-evaluation guidelines 20162020. Dublin: The Inspectorate.

Education Review Office (2016). Effective school evaluation: How to do and use internal evaluation for improvement. Wellington: Education Review Office.

Erden, M. (1998). Eğitimde program değerlendirme. Ankara: Anı Yayıncılık.

Fetterman, D. M., \& Wandersman, A. (2005). Empowerment evaluation principles in practice. NY: The Guilford Press.

Florida Department of Education (2012). School leader evaluation system observation and evaluation forms and procedures for leadership practice. Florida. 
Hanberger, A., Carlbaum, S., Hult, A., Lindgren, L., \& Lundström, U. (2016). School evaluation in Sweden in a local perspective: A synthesis. Education Inquiry, 7(3), 349371.

Learning Sciences Marzano Center (2012). Marzano school leadership evaluation model. Florida: Learning Sciences Marzano Center for Teacher and Leadership Evaluation.

Learning Sciences Marzano Center (2013). Developing a passion for professional teaching: The Marzano teacher evaluation model. Florida: Learning Sciences Marzano Center for Teacher and Leadership Evaluation.

Lincoln, Y. S. \& Guba, E. G. (1985). Naturalistic inquiry. Beverly Hills, CA: Sega.

MacBeath, J., Schratz, M., Meuret, D., \& Jakobsen, L. (2000). Self-evaluation in European schools: A story of change. Newyork: Taylor \& Francis Group.

MacBeath, J., \& Sugimine, (2003). Self-evaluation in the global classroom. Newyork: Taylor \& Francis Group.

MacBeath, J. (2006). School inspection and self-evaluation: Working with the new relationship. Newyork: Taylor \& Francis Group.

Marvasti, A. B. (2004). Qualitative research in sociology. USA: Sage Publications.

Mason, J. (2002). Qualitative Researching. (2nd ed.). London: Sage Publication.

Merriam, S. B. (2009). Qualitative research: A guide to design and implementation. California: John Wiley \& Sons, Inc.

National Policy Board for Educational Administration (2008). Educational Leadership Policy Standards. Washington, DC: Council of Chief State School Officers.

National Research Council (2011). Assessing 21st Century Skills: Summary of a Workshop. Washington, DC: The National Academies Press.

Nevo, D. (2002). School-based evaluation: An international perspective. (1st ed.). UK: Elsevier Science.

Ornstein, A., \& Hunkins, F. (2009). Eğitim programı: Temeller, ilkeler ve sorunlar. (A. Ar1, 2016) Konya: Eğitim Yayınevi.

Öğretmen Yetiştirme ve Eğitimi Genel Müdürlüğü (2002). Öğretmen yeterlilikleri. Ankara: Milli Eğitim Basımevi.

Parent Teacher Association (2009). PTA national standards for family-school partnerships: An implementation guide. USA, 1-70.

Partnership for 21st Century Learning (2015). Framework for 21st Century Learning. Washington DC, 1-9.

Rogers, G., \& Badham, L. (1992). Evaluation in schools: Getting started on training and implementation. Newyork: Taylor \& Francis Group. 
Sapsford, R., \& Jupp, V. (2006). Data collection and analysis. (2nd ed.). London: Sage Publication.

Saylor, J. G., Alexander, M. W., \& Lewis, A. J. (1981). Curriculum Planning for better teaching and learning. Holt, Rineheart and Winston Inc.

Sönmez,V., \& Alacapınar, F. G. (2015). Örnekleriyle eğitimde program değerlendirme. Ankara: Anı Yayıncilık.

Stake, R. E. (1967). The Countenance of Educational Evaluation. Teachers College Record, 68, 523-540.

Stufflebeam, D. L., \& Shinkfield, A. J. (1988). Systematic evaluation: A self.instructional guide to theory and practice. (3rd ed.). MA: Kluwer-Nijhoff Publishing.

Şimşek, H. (2009). Eğitim tarihi araştırmalarında yöntem sorunu. Ankara Üniversitesi Eğitim Bilimleri Fakültesi Dergisi, 42(1), 33-51.

Unterman, R., Bloom, D., Byndloss, D. C., \& Terwelp, E. (2016). Going away to school: An evaluation of SEED DC. USA: MDRC.

Watkins, R., Meiers, M. W., \& Visser, Y. L. (2012). A guide to assessing needs. Washington DC: International Bank for Reconstruction and Development.

Wholey, J. S., Hatry, H. P., \& Newcomer, K. E. (2004). Handbook of practical program evaluation. (2nd ed.). CA: Jossey-Bass.

Yüksek Öğretim Kurulu (1999). Türkiye'de öğretmen eğitiminde standartlar ve akreditasyon. Ankara. 